\title{
Housing Deficit Attenuation Through Market-Oriented Polycentric Management: Evidence from Nigeria
}

\author{
Nonso Izuchukwu Ewurum ${ }^{1} \quad$ Nkiruka Evangeline Aso $^{2} \quad$ Ijeoma Clara Ewurum $^{3}$ \\ 1.Estate Management, University of Nigeria Nsukka, Enugu, Nigeria \\ 2.Estate Management, Nnamdi Azikiwe University, Awka, Anambra, Nigeria \\ 3.Business Studies, University School Enugu Campus, Enugu, Nigeria
}

\begin{abstract}
With a household renumeration of 39 million, 2.6\% annual population growth rate, the over 17 million housing deficit in Nigeria is colossal, and remarkably unsustainable. Public housing providers in Nigeria have approached the scourge through a plethora of economic, financial and social strategies that have been proclaimed ineffective from various empirical standpoints. This paper investigates the market-oriented polycentricity of housing deficit attenuation in Nigeria. Survey method was employed on a sample frame of 384 public housing providers. Data was collected using a Market Orientation and Service Performance modelled questionnaire. Hypotheses testing employed Wilcoxon Signed Rank-Test and Spearman Rank Order Correlation. Results indicate that public housing delivery in Nigeria has not followed a market-oriented polycentric approach. The study recommended a consideration of this in the delivery of public housing, while advocating for the development of a Stakeholder Identification Framework for sustainable public housing delivery.

Keywords: Housing deficit, Housing delivery, Polycentric management, Market orientation, Stakeholder identification, Demography management

DOI: $10.7176 / \mathrm{DCS} / 10-3-05$

Publication date:March $31^{\text {st }} 2020$

$\begin{array}{ll}\text { Acronyms } & \\ \text { Listed in alphabetical order as follows: } \\ \text { BSIPDCL: } & \text { Bauchi State Investment and Property Development Company Limited } \\ \text { CBA: } & \text { Cost Benefit Analysis } \\ \text { DM: } & \text { Demography Management } \\ \text { ESHDC: } & \text { Enugu State Housing Development Corporation } \\ \text { FHA: } & \text { Federal Housing Authority } \\ \text { FMBN: } & \text { Federal Mortgage Bank of Nigeria } \\ \text { KSDPC: } & \text { Kaduna State Development and Property Company } \\ \text { LSDPC: } & \text { Lagos State Development and Property Corporation } \\ \text { MARKOR: } & \text { Market Orientation } \\ \text { MH: } & \text { Ministry of Housing } \\ \text { MHUD: } & \text { Ministry of Housing and Urban Development } \\ \text { MKTOR: } & \text { Market Orientation } \\ \text { MO: } & \text { Market Orientation } \\ \text { MR: } & \text { Market Research } \\ \text { PHC: } & \text { Plateau State Housing Corporation } \\ \text { PHD: } & \text { Public Housing Delivery } \\ \text { PHP: } & \text { Public Housing Providers } \\ \text { PIPDCL: } & \text { Plateau Investment and Property Development Company Limited } \\ \text { REDAN: } & \text { Real Estate Developers Association of Nigeria } \\ \text { RSHPDA: } & \text { Rivers State Housing and Property Development Authority } \\ \text { SI: } & \text { Stakeholder Identification } \\ \text { UHD: } & \text { Urban Housing Deficit } \\ & \end{array}$
\end{abstract}

\section{Primer}

With a household renumeration of 39 million, the over 17 million housing deficit in Nigeria (World Bank, 2016) is colossal, realistically overwhelming and worryingly on an upward spate. To address this spate of housing deficit in the country, public housing providers in Nigeria (housing development corporations, ministries, mortgage finance institutions, public private partnerships) have come up with economic, financial and social strategies such as public private partnerships, cooperative housing development loans, National Housing Mortgage Fund, and rent-to-own schemes. However, empirical evidence suggests that these strategies are at best cosmetic and realistically ineffectual in tackling the deficit, given the country's annual aggregate housing development index of 100,000 units (Delmendo, 2019) as compared to the World Bank's recommended annual aggregate housing 
development index of 700,000 units. Given an annual population growth rate of $2.6 \%$ (World Bank, 2016), the situation is deficient in economic and social sustainability.

\section{Review}

Scholars have offered an array of reasons for Nigeria's slow progress, if any, in combating the housing deficit. Ezeigwe (2015) avers that predictors of urban housing deficit in Nigeria are poverty, urbanization, high cost of land, non-implementation of the housing policies, failure on the side of the government, high cost of building materials and corruption. In their take, Olanrewaju et al. (2016) argue that ineffective policies and regulations, legal issues, ineffective market regulation, and high cost of construction are the reasons for the deficit. Ewurum and Odenigbo (2018) levelled the blame on ineffectual demography management and affordability, defining demography management as the integration of population statistics in decision making. The affordability angle also finds support in the works of Ahmed and Bin Sipan (2019), Okafor (2016) and Ifediora et al. (2015) who posit that low-income earners are the predominant demography of housing deficit in Nigeria.

This then portends that addressing housing needs of low-income earners is effective in attenuating the housing deficit in the country. Low-income earners are considered those whose household's disposable money income per consumption unit (equivalent income) is lower than 60 per cent of the equivalent median money income of all households (Ewurum et al, 2018). The United Nations refers to them as persons at risk of poverty. Justifying the low-income earner argument, Okafor (2016) extrapolates that housing deficit in Nigeria emanates from an agglomeration of lack or inadequate housing financial assistance, high cost of building materials, high interest rate and lukewarm interest on the part of financial institutions to facilitate loans to real estate developers. In view of Okafor's (2016) assertion, where then are the government's public private partnerships, cooperative housing development loans, National Housing Mortgage Fund, and rent-to-own schemes (pardon the repetition) implemented?

Lending credence to this query, Ahmed et al (2019) posit that public housing delivery in Nigeria is characterized by "lack of proper framework which includes, land accessibility and affordability, corruption, lack of sound legal framework, funding constraints, and unstable price of building material". Ifediora et al (2015) hold that these characteristics are consequential upon "little or no market research, poor direction, poor project locations, stringent affordability criteria, corruption, and lack of trust by the masses".

Expanding the narrative, Gbadegesin et al. (2016) implicated tenure security and land availability as major causes of urban housing deficit in Nigeria. This contribution brings the Nigerian Land Use Act (1978) into focus, if not into disrepute. Presented with this fact, one is bound to ask - since the Land Use Act was enacted to make land available for development through government control of tenure and use, why then is land not available for development? Ezeigwe (2015) attempts a response with the avowal that the process is littered with corruption which transmutes the policy from societal welfare to private benefit.

A synthesis of these empirical presentations reveals the following. First, low income earners make up the bulk of housing deficit demography in Nigeria. Second, Nigeria produces a deficit renumeration of 600,000 housing units annually; and this implies that with an annual population growth rate of almost $3 \%$, instead of reducing the deficit, it seems that Nigeria is subconsciously increasing the deficit. Third, attempts by public housing providers in Nigeria to curb the deficit have been misdirected and has not prioritized the demands of the predominant demography. Delmendo (2019) concurs, with the assertion that in Lagos Nigeria, over $70 \%$ of the population live in informal settlements and slums, a situation that is rife all over the country (Ademiluyi, 2010). This disturbing statistic is explained by Akinlose (2019) who avers that supply of new homes in Lagos Mainland is significantly lower than in the Lagos Island axis. For the purpose of clarity, Lagos Island axis covers Victoria Island, Ikoyi and Lekki, areas characterized by mainly middle and higher-income groups.

Lending credence, Ahmed et al (2019) allege that public housing delivery in Nigeria has benefitted mostly the middle to high-income demography. By implication, given the acknowledgement of misdirected priority, ineffective policy implementation, affordability, financial nonviability and inflexibility, high construction costs, and ineffectual demography management as bane of housing deficit in Nigeria, a market disorientation culture begins to form. To explain market disorientation, we first explain market orientation. Market orientation is a means of attaining sustainable organizational performance and competitive positioning, through needs-based approach to service delivery (Leal-Rodríguez and Albort-Morant, 2016). In elucidating the parameters for adopting market orientation in organizational and project settings, we refer to Tomášková's (2009) synthesis of the MKTOR and MARKOR models.

MKTOR developed by Narver and Slater (1990) is an acronym for market orientation. The model disintegrates market orientation into 3 constructs of "customer orientation, competitor orientation and interfunctional co-ordination". Brännback (1999) defines customer orientation as the identification of current and future customer needs for the purpose of satisfying those needs. Competitor orientation, on the other hand, is a strategy of beating competition in the market through prioritizing competitive positioning over profit maximization (Bendle and Vandenbosch, 2014). The relevance of this assertion to public housing delivery lies in the social welfare motive 
of government as against any profit maximization tendency.

Tomášková (2009) further grouped the customer and competitor facets into one umbrella tagged - stakeholder orientation. Stakeholder orientation is the relative attention an organization gives to its employees (as internal stakeholders), customers, community, and the natural environment (as external stakeholders) (Liu and Reid, 2019). This attention entails the identification and engagement of stakeholders in service delivery, where identification is premised upon Freeman's (1984) Stakeholder Identification theory on recognition and documentation of groups vital to organizational performance. While external stakeholder orientation conforms more to the market orientation hypothesis, the internal aspect that deals with employees is more related to inter-functional coordination. Lending credence, Kanovska and Tomášková (2012) opine that inter-functional coordination is the "coordination of all company activities leading to the increase of business performance". This extrapolation recognizes the employee as an organ of the organization's market.

We juxtapose the stakeholder orientation argument with Nigeria's stakeholder identification framework which rightly recognizes regulators, financiers and developers (Pison Housing Company, 2010 in EFInA and FinMark Trust, 2010). According to the framework, regulators are the Central Bank of Nigeria, Federal Ministry of Lands, Securities and Exchange Commission and Federal Ministry of Housing. Financial Institutions are the Federal Mortgage Bank of Nigeria, Primary Mortgage Institutions, Insurance Companies and Deposit Money Banks. Developers recognized in the framework are the State Ministries of Lands, the Federal Housing Authority, the State Housing Development Corporations, Real Estate Developers Association of Nigeria and the State Ministries of Housing.

Yet, it is conspicuous that a cursory examination of this framework shows that the end-user may not be recognized by Nigerian public housing providers as a stakeholder. Clarkson (1995) refutes this approach with the identification of stakeholders in public administration as "the government that provide infrastructure (such as housing), whose laws must be obeyed, and to whom taxes and other obligations may be due; and the communities who are beneficiaries of the infrastructure, and liable to pay the taxes". It is interestingly evident from Clarkson's (1995) argument that sustainable infrastructural delivery depends on its economic and social sustainability disposition.

Citing another flaw in the framework is Ewurum et al.'s (2019) observation of an equally conspicuous absence of the academia. They argue that "the extent to which contributions of studies as this are utilized in national and economic planning is relatively not encouraging". Even if Scholars are consulted during the housing delivery process, what evidence suggests that novel empirical recommendations are implemented by housing providers at every stage of the process. Also running contrary to Freeman (1984), is the framework's unrecognition of "NonGovernmental Organizations (local and international), cooperative societies, representatives of relevant international agencies such as United Nations Development Programme (UNDP), and the World Bank as crucial stakeholders". In this context, the study goes further as an empirical examination of the processes employed by public housing providers in Nigeria in engaging the end-user, community and market interests across the 6 geopolitical zones of the country. Therefore, we hypothesize as follows:

HI: $\quad$ To a large extent, stakeholder identification is not utilized in public housing delivery in Nigeria.

The MARKOR model, also an acronym for market orientation was developed by Kohli and Jaworski (1993). It sees market orientation as the trinity of gaining information, disseminating the information, and utilizing same information through organizational response. This is indicative of a culture of customer needs-based service delivery. Information is gained by the organization through market research, which is the identification, collection, analysis, dissemination and utilization of information for improved decision making (Brochado, 2020). Could Delmendo's (2019) and Akinlose's (2019) report on public housing delivery in Lagos in this regard, be indictive on the public housing delivery system in Nigeria? Following the empiricism of this query as akin to Lagos Nigeria, our conjecture is as follows:

HII: $\quad$ To a large extent, market research is not utilized by Nigerian public housing providers.

HIII: Demography management is associated with urban housing deficit in Nigeria.

\section{Theoretical Foundation: Polycentric Governance Theory (Carlisle and Gruby, 2019)}

A precis of the prescriptions of MKTOR and MARKOR models show that organizations who are responsive to intelligence gained from employees, customers, competitors, consultants and the natural environment in service planning and delivery, are market-oriented organizations. This is consistent with the polycentric governance theory (Carlisle and Gruby, 2019) on which this work is anchored on. The Theory argues that sustainable service delivery is attained through decentralized governance. The relevance of polycentric management system to our analysis is premised on the argument that decentralized decision-making can be achieved through stakeholder collaboration. This is the most effective model of service delivery in democratic societies (Pahl-Wostl and Knieper, 2014).

By this, we conceptualize market orientation as a polycentric approach to sustainable organizational performance through identification and implementation of customer needs in service planning and delivery. In other words, it is a bottom-up approach to service delivery (Ifediora et al, 2015). Marshall (2015) argues that 
polycentricity is not only achieved through decentralization, instead it must incorporate intelligence gained from the collaboration. This sums up the thesis of market orientation (Taborecka-Petrovicova, 2018; Šályová et al., 2015). By implication then, market disorientation is a top-bottom approach to service delivery without due cognizance to stakeholder input. Organizations who employ this approach are hardly sustainable and are characterized by inefficiency and service failures (Ifediora, 2017).

On the other hand, research has shown that market-oriented organizations perform better than marketdisoriented organizations through business intelligence management that bothers on collection, dissemination of, and responsiveness to market-based information (Budinska and Taborecka-Petrovicova, 2018; Ifediora et al, 2015; Šályová et al, 2015). This consensual foundation of market orientation is consistent with the MKTOR and MARKOR theories of market orientation, and the Polycentric Governance Theory.

\section{Market Orientation of Public Housing Delivery: A Perspective}

In spite of the empirical synthesis which suggests a perceived market disorientation behavior of Nigerian public housing providers, it is also clear that the discourse has remained largely unexplored and speculative as a concentrated effort. Specifically, empirical submissions on the reasons for the ameliorated housing deficit in Nigeria were spatially sectorial, and not significantly scoped on market orientation. To confirm the veracity of this claim and further justify the study, we conducted a tailored meta-analysis to compare the prevalent empirical knowledge on market orientation with our 'applicable region' of housing delivery, in consistence with Willis and Hyde (2014) and Van der Gaag et al. (2014). To establish the test positive rate and the prevalent rate, our relevant construct development was based on a linkage of market orientation and public housing delivery on the Web of Science and Google Scholar databases in 2019.

In the identification of variable groups, the control group (MO) showed over 3,250,000 presentations and simulations of market orientation amongst diverse industries on both databases. However, for our experimental group (MO-PHD), the result was only 7 contributions globally. Of the 7 contributions, 1 was domiciled in Zimbabwe (Davies and Dewar, 1989), 1 in Italy (Amenta and Di Betta, 2010), 1 in China (Li et al, 2016), while 4 (Ifediora, 2017; Ifediora et al, 2015; Ifediora et al., 2015b; and Ndubueze, 2009) were domiciled in Nigeria. Thereafter, analysis with Glass's Delta was conducted to establish the variations between the control and experimental for further division with the control groups' Standard Deviation (Black et al, 2010; Kingsep et al., 2003). We discuss the findings of the tailored meta-analysis in the following paragraphs.

Davies et al (1989) was deemed relatively irrelevant to the MO-PHD construct due to its focus on the role of the housing process in social transformation. We attribute same decision on Amenta et al (2010) due to their emphasis on football clubs" "corporate social responsibility and marketing strategies" within their host communities. Li et al (2016), Ifediora (2017), Ifediora et al (2015; 2015b) and Ndubueze (2009) are more related to the MO-PHD construct. Li et al (2016) investigated "the financial sustainability of Public Rental Housing projects in China, from the perspective of the private sector". By implication, the study focuses more on the role of the private sector in the provision of affordable housing, thus deviating from our market-oriented approach to housing deficit attenuation.

In Nigeria, Ndubueze's (2009) doctoral thesis developed a model for measuring housing affordability in Nigeria. Although the study is financial-driven in consistence with Li et al (2016), it further establishes the grounds for our investigation into the MO-PHD nexus, with its finding that shows "very high levels of housing affordability problems in Nigeria with about 3 out of every 5 urban households experiencing such difficulties". While our earlier spatially sectorial argument does not hold for Ndubueze (2009), Ifediora (2017), and Ifediora et al (2015; 2015b) given that they share our country-level approach, they still did not incorporate the stakeholder identification and demography management constructs employed in this study.

Also of pertinence is the noted disparity evinced by Ifediora's (2017) and Ifediora et al's (2015; 2015b) use of Lozano's (2000) customer orientation checklist model on respondents from the National Housing Fund, as against our adoption of Singh's (2005) Market Orientation and Service Performance construct on respondents from Federal Mortgage Bank of Nigeria, Federal Housing Authority, REDAN, State Ministries of Housing, and State Housing Development Corporations. From the foregoing, there is need for a more specific investigation of the adoption of market orientation by public housing providers in Nigeria, without which any such perception of market disorientation may be argued away as hypothetical.

The study therefore, extricates other identified public housing deficit predictors such as finance, corruption, affordability, and lays particular emphasis on the stakeholder identification/customer orientation, market research and demography management constructs of market orientation in the examination of public housing delivery in Nigeria. This approach to the investigation follows the submissions of the MKTOR, MARKOR and Polycentric Governance Models. To the best of our knowledge, the study is the first to underscore public housing delivery through strategic polycentricity-market orientation linkage. From the foregoing we develop the following research questions: 
I. To what extent is stakeholder identification utilized in public housing delivery in Nigeria?

II. To what extent is market research utilized by Nigerian public housing providers?

III. What is the correlation between demography management and urban housing deficit in Nigeria?

\section{Methodology}

The study employed descriptive research design. Data were obtained from primary sources through the use of a 5point Likert Scale questionnaire designed in consistence with the research questions. The make-up of the questionnaire items was modeled from the Singh (2005) Market Orientation and Service Performance construct. Respondents were invited to rate the extent of utilizing market orientation in the delivery of public housing on a 5-point Likert scale of:

$\begin{array}{lll}5 & = & \text { Very Large Extent } \\ 4 & = & \text { Large Extent } \\ 3 & = & \text { Moderate Extent } \\ 2 & = & \text { Low Extent } \\ 1 & = & \text { Very Low Extent }\end{array}$

An insignificant score of 0 was used in weighing nonresponses and undecided categories.

The sample frame comprised Federal Housing Authority (FHA), State Housing Development Corporations, Ministry of Housing and Urban Development (MHUD), Federal Mortgage Bank of Nigeria (FMBN), and Real Estate Developers' Association of Nigeria (REDAN) in all 6 geopolitical zones of Nigeria. Freund and Williams statistical formula was used to determine the sample size of 384 . Purposive sampling was employed both in data collection, and in the selection of one State from each zone, as shown in Table 1.

Table 1. Population Distribution by Geopolitical Zone

\section{Geopolitical Zone}

North Central

North East

North West

South East

South-South

South West

\section{State}

Plateau

Bauchi

Kaduna

Enugu

Rivers

Lagos
Public Housing Providers MHUD, PHC, FMBN, PIPDCL, REDAN FHA, REDAN, MH, FMBN, BSIPDCL MHUD, KSDPC, FMBN, FHA ESHDC, MHUD, FHA, REDAN, FMBN RSHPDA, FHA, FMBN, REDAN, MH FHA, LSDPC, FMBN, MH, REDAN

Source: Field Survey (2020)

Table 1 shows the distribution of public housing providers in accordance with each utilized State from the 6 geopolitical zones of Nigeria. The use of REDAN was informed by the Public-Private Partnership schemes of the government housing ministries, departments and agencies.

The data collection process spanned a period of 5 weeks, and utilized the services of 9 paid research assistants in addition to the 3 researchers. Questionnaire return rate was $81 \%$, and as this rate surpassed $65 \%$ acceptable rate for questionnaires, it was deemed valid (Arber, 2001; Sitzia and Wood, 1998; Kelley et al, 2003). The survey was based on execution level experience of public housing delivery mechanisms in the country. Following the Singh (2005) Market Orientation and Service Performance construct, the questionnaire was adapted to elicit the following data on the application of MO-Responsiveness paradigms to a housing perspective:

RQI: $\quad$ SI-PHD

i. Stakeholder Analysis

ii. Public Participation

iii. $\quad$ Valuing Stakeholder Input

iv. Continuous Mandatory Human Capital Development

RQII: $\quad$ MR-PHP

i. $\quad$ Customer Needs Determination Investment

ii. Regular Customer Needs Intelligence Gathering

iii. Customer Needs drive Decision Making

iv. $\quad$ Evaluation of Project Externalities to Environment

v. Operation-level Staff has Requisite Marketing Experience

RQIII: DM-UHD

i. $\quad$ Service is Market Segment-Driven

ii. $\quad$ Prioritized Customer Needs Drive Decision Making

RESPONSIVENESS

i. $\quad$ Flexibility of Policy Implementation to Match Customer Needs

ii. Sustainability-driven Cost-Benefit Analysis

iii. House Price Adaptability

iv. Policy Revalidation

As stipulated by the model, MO is the independent variable, while Responsiveness of Public Housing 
Providers represented the dependent variable of the study. A weighted mean ranging from 0 to 2.5 implies weak MO; a weighted mean ranging from 2.6 to 3.5 implies medium MO; while a weighted mean ranging from 3.6 to 5 implies strong MO (Singh, 2005). This laid the ground for testing the hypotheses using Wilcoxon Signed RankTest and Spearman Rank Order Correlation due to the ordinal physiognomy of our data.

The Wilcoxon Signed Rank-Test, used in testing hypotheses I and II, was employed to match samples obtained from both independent and dependent variable indicators with a view to determining the variation in their population mean (Rosner et al., 2006; Woolson, 2008). The decision rule is to reject the null hypothesis where the critical z-value equals or is greater than 1.96, representing $\mathrm{z}$-value at $95 \%$ confidence interval (or a $5 \%$ level of significance). We used Spearman Rank Order Correlation to determine the strength and direction of the relationship between the ranked demography management and urban housing deficit variables in hypothesis III (Spearman, 1904; Gilmore et al., 2019). The decision rule is to accept the alternate hypotheses when the probability value is less than alpha level of 0.05 , otherwise do not reject the null hypotheses.

\section{Results}

Research Question One investigated the extent to which stakeholder identification is utilized in public housing delivery in Nigeria. Table 2 reveals the results obtained from the operationalization of this query.

Table 2. Utilization of Stakeholder Identification in Public Housing Delivery in Nigeria

\begin{tabular}{|c|c|c|c|c|c|c|}
\hline S/No. & Statement & $N$ & Minimum & Maximum & $\begin{array}{l}\text { Weighted } \\
\text { Mean }\end{array}$ & Verdict \\
\hline 1 & $\begin{array}{l}\text { Stakeholder analysis is used to make house } \\
\text { prices more adaptable to beneficiary } \\
\text { population }\end{array}$ & 311 & 1.00 & 4.00 & 2.94 & $\begin{array}{l}\text { Medium } \\
\text { MO }\end{array}$ \\
\hline 2 & $\begin{array}{l}\text { Changes are made to policy implementation } \\
\text { to cater for public participation outcomes }\end{array}$ & 311 & 1.00 & 4.00 & 1.37 & $\begin{array}{l}\text { Weak } \\
\text { MO }\end{array}$ \\
\hline 3 & $\begin{array}{l}\text { Valuing stakeholder input has made CBA } \\
\text { more sustainable }\end{array}$ & 311 & 1.00 & 5.00 & 1.91 & $\begin{array}{l}\text { Weak } \\
\text { MO }\end{array}$ \\
\hline 4 & $\begin{array}{lccc}\text { Continuous } & \text { mandatory } & \text { human } & \text { capital } \\
\text { development } & \text { has } & \text { made } & \text { policy }\end{array}$ & 311 & 1.00 & 4.00 & 2.72 & $\begin{array}{l}\text { Medium } \\
\text { MO }\end{array}$ \\
\hline
\end{tabular}
implementation more flexible to accommodate customer needs

Source: Field Survey (2020)

Table 2 shows a weak-medium MO dichotomy amongst all customer identification and recognition-based enquiries, thus signifying that the PHD process is not satisfactorily market oriented. However, the Medium MO observed in stakeholder analysis suggests that stakeholder identification is not inexistent in public housing delivery.

\subsection{Analysis}

We also subject the results to analysis with Wilcoxon Signed Rank Test.

Wilcoxon Signed Ranks Test

\section{Ranks}

\begin{tabular}{|ll|l|l|l|}
\hline & N & Mean Rank & Sum of Ranks \\
\hline stakeholder_identification2 & -Negative Ranks & $2^{\mathrm{a}}$ & 4.00 & 8.00 \\
Stakeholder_Identification1 & Positive Ranks & $3^{\mathrm{b}}$ & 2.33 & 7.00 \\
& Ties & $0^{\mathrm{c}}$ & & \\
& Total & 5 & & \\
& & & \\
&
\end{tabular}

a. stakeholder_identification $2<$ Stakeholder_Identification 1

b. stakeholder identification $2>$ Stakeholder Identification 1

c. stakeholder_identification $2=$ Stakeholder_Identification 1

Test Statistics

\begin{tabular}{|l|l|}
\hline & $\begin{array}{l}\text { stakeholder_identification2 } \\
\text { Stakeholder_Identification1 }\end{array}$ \\
\hline Z & $-.137^{\mathrm{a}}$ \\
Asymp. Sig. (2-tailed) & .891 \\
\hline
\end{tabular}

a. Based on negative ranks.

b. Wilcoxon Signed Ranks Test

Decision: Since $\mathrm{z}=-.137(<1.96)$, we do not reject the null hypothesis. Therefore, to a large extent, stakeholder identification is not utilized in public housing delivery in Nigeria. 
Research Question Two investigated the extent to which market research is utilized by Nigerian public housing providers. Table 3 reveals the results obtained from the operationalization of this query.

Table 3. Utilization of Market Research by Public Housing Providers in Nigeria

\begin{tabular}{l|llllll} 
S/No. & Statement & $N$ & Minimum & Maximum & $\begin{array}{l}\text { Weighted } \\
\text { Mean }\end{array}$ & Verdict \\
\hline 1 & $\begin{array}{l}\text { There is allocated budget for determination } \\
\text { of customer needs }\end{array}$ & 311 & 1.00 & 5.00 & 1.91 & Weak MO \\
2 & $\begin{array}{l}\text { Regular intelligence gathering on customer } \\
\text { needs leads to policy validation }\end{array}$ & 311 & 1.00 & 5.00 & 1.08 & Weak MO \\
3 & $\begin{array}{l}\text { Decision making is customer needs-driven } \\
\text { Evaluation of project externalities to } \\
\text { environment is sustainability-driven }\end{array}$ & & & & \\
Operation-level staff has requisite \\
marketing experience 311
\end{tabular}

Source: Field Survey (2020)

Table 3 shows that all market research-based enquiries produced a Weak MO signifying that PHPs are not market oriented. However, the Medium MO observed in the project externality to environment query shows the integration of triple bottom sustainability by PHPs in Nigeria, albeit minimal.

\subsection{Analysis}

We subject the results to analysis with Wilcoxon Signed Rank Test.

Wilcoxon Signed Ranks Test

\section{Ranks}

\begin{tabular}{|ll|l|l|l|}
\hline & $\mathrm{N}$ & Mean Rank & Sum of Ranks \\
\hline market_research2 & -Negative Ranks & $2^{\mathrm{a}}$ & 2.00 & 4.00 \\
Market_Research1 & Positive Ranks & $2^{\mathrm{b}}$ & 3.00 & 6.00 \\
& Ties & $1^{\mathrm{c}}$ & & \\
& Total & 5 & & \\
\hline
\end{tabular}

a. market_research $2<$ Market_Research1

b. market_research2 $>$ Market_Research1

c. market research2 $=$ Market Research1

Test Statistics ${ }^{\mathrm{b}}$

\begin{tabular}{|l|l|}
\hline \multicolumn{1}{|l|}{} & $\begin{array}{l}\text { market_research2 } \\
\text { Market_Research1 }\end{array}$ \\
\hline$Z$ & $-.378^{\mathrm{a}}$ \\
Asymp. Sig. (2-tailed) & .705 \\
\hline
\end{tabular}

a. Based on negative ranks.

b. Wilcoxon Signed Ranks Test

Decision: Since $\mathrm{z}=-.378(<1.96)$, we do not reject the null hypothesis. Therefore, to a large extent, market research is not utilized by Nigerian public housing providers.

Research Question Three investigated the correlation between demography management and urban housing deficit in Nigeria. Table 4 shows the results obtained from the operationalization of this query.

Table 4. Demography Management and Urban Housing Deficit in Nigeria

\begin{tabular}{|c|c|c|c|c|c|c|c|}
\hline S/No. & Statement & & $N$ & Minimum & Maximum & $\begin{array}{l}\text { Weighted } \\
\text { Mean }\end{array}$ & Verdict \\
\hline 1 & $\begin{array}{l}\text { Service Delivery is } \\
\text { Segment-Driven }\end{array}$ & Market & 311 & 1.00 & 4.00 & 4.18 & Strong MO \\
\hline 2 & $\begin{array}{l}\text { Prioritized Customer } \\
\text { Drive Decision Making }\end{array}$ & Needs & 311 & 1.00 & 5.00 & 1.46 & Weak MO \\
\hline
\end{tabular}

Source: Field Survey (2020)

From Table 4, it could be observed that PHD in Nigeria is market segment-driven as indicated by a Strong MO of 4.18. However, the Weak MO of 1.46 observed in whether customer needs are prioritized in decision making, explains that while PHD is market segment-driven, it was not prioritizing the market segment with the highest demand.

\subsection{Analysis}

We subject the results to analysis with Spearman Rank Order Correlation. 
Table 5. Descriptive Statistics

\begin{tabular}{|l|l|l|l|}
\hline & Mean & Std. Deviation & $\mathrm{N}$ \\
\hline Demography Management & 1.8845 & 1.04327 & 311 \\
Urban Housing Deficit & 2.2450 & 1.08782 & 311 \\
\hline
\end{tabular}

Table 5 displays the descriptive statistics of demography management. DM had a mean score of 1.8845, standard deviation of 1.04327 and number of cases 311; UHD had score of 2.2450, standard deviation of 1.08782 and number of cases as 311 .

Table 6. Correlation Measures

\begin{tabular}{||l||lll||}
\hline \multicolumn{1}{|l||}{} & \multicolumn{3}{|c||}{ Asymp. Std. } \\
\hline Correlations & Value & Error & Approx. Sig. \\
\hline Contingency Coefficient & 0.184 & 0.081 & 0.000 \\
Pearson's R & 0.039 & 0.067 & 0.000 \\
Spearman Correlation & 0.199 & 0.067 & 0.000 \\
\hline N of Valid Cases & 311 & & \\
\hline
\end{tabular}

Table 6 is the Spearman Rank Order correlation matrix on the strength and direction of the association between both variables as indicated by the correlation coefficients, significant values and the number of cases. The correlation coefficient shows 0.199 . This value indicates that correlation is weak at 0.00 level (2tailed).

Decision: Since $p<0.05$, we reject the null hypothesis. Therefore, we conclude that demography management is associated with urban housing deficit in Nigeria $(r=.199, \mathrm{p}<0.05)$.

\section{Findings}

1. To a large extent, stakeholder identification was not utilized in public housing delivery in Nigeria $(\mathrm{z}=-.137)$

2. To a large extent, market research was not utilized by Nigerian public housing providers $(\mathrm{z}=-.378)$.

3. Demography management was associated with urban housing deficit in Nigeria $(r=.199, p<0.05)$.

\section{Conclusion and Recommendations}

From the findings, the study concluded that public housing delivery in Nigeria is not market oriented, and therefore is not polycentric management-compliant. This position is informed by the ineffective stakeholder identification and market research process employed by public housing providers. The indication is that management approach to attenuating the over 17 million housing deficit in the country is not polycentric, and is more top-to-bottom. This lack of polycentricity implies that demographic management is encumbered by inadequate market intelligence.

Following the market disorientation behavior of public housing delivery in Nigeria, the development of a new Stakeholder Identification Framework has become more imperative, and is thus recommended by the study. The Framework should internalize the inter-functional coordination aspect of the MKTOR model through a recognition of employees as stakeholders who must be trained to be market orientation savvy. This would enable a prioritization of market orientation through assimilated intelligence for effective demography management. Finally, while the study recognizes that Nigerian public housing providers have not totally neglected the end-user, we advocate for increased empirical attention to the market orientation-public housing delivery nexus to broaden their perspective on the subject.

\section{Practical Implication}

The study argues that a market-oriented polycentric approach should be considered in the delivery of public housing. Public housing providers who adopt this argument stand better chance of achieving economic and social sustainability in the public housing delivery system.

\section{Originality}

To the best of the authors' knowledge, the study is at the fore of addressing the attenuation of deficit in public housing delivery through strategic polycentricity-market orientation linkage.

\section{Conflict of Interest}

The authors declare no conflict of interest.

\section{Acknowledgements}

We are effusively grateful to the public housing delivery officials across the Ministries, Banks, Agencies and 
Associations who were kind enough to participate towards the successful conclusion of this study. We also extend our gratitude to the 9 research assistants who devoted time, effort and intellect towards the successful completion of the study.

\section{References}

Ademiluyi, I.A. (2010). Public housing delivery strategies in Nigeria: A historical perspective of policies and programmes. Journal of Sustainable Development in Africa, 12(6), 153-161.

Ahmed, Y. and Bin Sipan, I. (2019). Critical factors for implementation of public-private partnership for affordable housing in Nigeria. International Journal of Scientific \& Technology Research, 8(9). 1125-1131

Akinlose, O. (2019). The RAC Lagos house price index - 2018 outlook. https://estateintel.com/app/uploads/2018/03/RAC-Lagos-House-Price-Index-2018-Outlook.pdf, Retrieved on October, 2019.

Amenta, C. and Di Betta, P. (2010). You can even walk alone - Stadium attendance and professional soccer clubs' social role. International Journal of Business and Management, 1(1). Available at SSRN: https://ssrn.com/abstract=1975719

Arber, S. (2001). Designing samples. In: Gilbert N, ed. Researching Social Life. London: SAGE Publications.

Bendle, N. and Vandenbosch, M. (2014). Competitor orientation and the evolution of business markets. Marketing Science, 33(6), 781-795.

Black, C.D., Herring, M.P., Hurley, D.J. and O’Connor, P.J. (2010). Ginger (Zingiber officinale) Reduces Muscle Pain Caused by Eccentric Exercise. The Journal of Pain, 11(9), 894-903.

Brännback, M. (1999). The concept of customer-orientation and its implication for competence development. Department of Marketing, Turku School of Economics and Business Administration.

Brochado, A. (2020). An introduction to marketing research. https://www.fep.up.pt/disciplinas/lge508/Presentation\%201\%206_10_04.pdf, Retrieved January, 2020.

Budinska, S. and Taborecka-Petrovicova, J. (2018). Market orientation and business performance from behavioural perspective - The case of Slovakia. International Scientific Journal "Industry 4.0", 3(6), 330-334.

Carlisle, K. and Gruby, R.L. (2019). Polycentric systems of governance: A theoretical model for the commons. Policy Studies Journal, 47(4).

Clarkson, M. (1995). A stakeholder framework for analyzing and evaluating corporate social performance. Academy of Management Review, 20(1), 114-137.

Davies, J. and Dewar, N. (1989). Adaptive or structural transformation? The case of the Harare, Zimbabwe, housing system. Social Dynamics, 15(1), 46-60.

Delmendo, L.C. (2019). Nigeria's housing market stabilizing, amidst improving economic conditions. https://www.globalpropertyguide.com/Africa/Nigeria/Price-History, retrieved on December 12, 2019.

Der Gaag, M., Valmaggia, L.R. and Smit, F. (2014). The effects of individually tailored formulation-based cognitive behavioural therapy in auditory hallucinations and delusions: A meta-analysis. Schizophrenia Research, 156(1), 30-37.

Ewurum, N.I. and Odenigbo, O.A. (2018). Predictors of housing market disequilibrium in South-East Nigeria: Empirical evidence from Anambra and Enugu States. Sustainable Empirical Environmental Research Journal, 1(1): 1-27.

Ewurum, N.I., Egolum, C.C. and Ogbuefi, J.U. Stakeholder management strategy for sustainable public housing delivery in South East, Nigeria. Global Journal of Advanced Research, 6(3), 78 - 94.

Ezeigwe, P.C. (2015). Evaluation of the causes of housing problems in Nigeria: A case study of Awka the Capital City of Anambra State. Journal of Economics and Sustainable Development, 6(2)

Fontaine, C., Haarman, A. and Schmid, S. (2006). The Stakeholder Theory. Retrieved from https://pdfs.semanticscholar.org/606a/828294dafd62aeda92a77bd7e5d0a39af56f.pdf. in May, 2019

Freeman, R.E. (1984). Stakeholder Theory: The State of the Art. Cambridge: Cambridge University Press.

Gbadegesin, T., van der Heijden, H. and Boelhouwer, P. (2016). Land accessibility factors in urban housing provision in Nigeria Cities: Case of Lagos. Delivered at The European Network for Housing Research Conference: Governance, Territory and Housing, 1-15.

Gilmore, C.J., Barr, G. and Dong, W. (2019). Spearman's rank order coefficient. International Tables for Crystallography8.

Ifediora, C.U. (2017). Application of customer-driven marketing strategies to government housing development programmes in Nigeria. 196.222.5.9/handle/123456789/5351 (2019)

Ifediora, C.U., Igwe, A.A. and Ukpere, W.I. (2015). Assessment of incoporation of customers' specific affordability needs in the Nigeria National Housing Fund (NHF) scheme. Problems and Perspectives in Management, 13(3), 141.

Ifediora, C.U., Igwe, A.A. and Ukpere, W.I. (2015b). Appraisal of the adequacy of the application of customerdriven marketing strategies to the Nigeria National Housing Fund Scheme. Risk Governance \& Control: 
Financial Markets \& Institutions, 5(3), 67.

Kanovska, L. and Tomaskova, E. (2012). Interfunctional Coordination at Hi-Tech Firms. Inzinerine EkonomikaEngineering Economics, 23(1), 70-76

Kelley, K., Clark, B., Brown, V, and Sitzia, J. (2003). Good practice in the conduct and reporting of survey research, International Journal for Quality in Health Care, 15(3), 261266, https://doi.org/10.1093/intqhe/mzg031.

Kingsep, P., Nathan, P. and Castle, D. (2003). Cognitive behavioural group treatment for social anxiety in schizophrenia. Schizophrenia Research, 63(1-2), 121-129

Kohli, A. K., Jaworski, B. J. and Kumar, A. (1993). MARKOR: A Measure of Market Orientation. Journal of Marketing Research, 30, 467 - 477.

Leal-Rodríguez, A. and Albort-Morant, G. (2016). Linking market orientation, innovation and performance: An empirical study on small industrial enterprises in Spain. Journal of Small Business Strategy, 26(1).

Li, D., Chen, Y., Chen, H., Hui, E.C.M. and Guo, K. (2016). Evaluation and optimization of the financial sustainability of public rental housing projects: A case study in Nanjing, China. Sustainability, 8, 330.

Liu, X.K. and Reid, C.D. (2019). Stakeholder orientations and cost management. Contemporary Accounting Research, 36(1), 486-512.

Marshall, G.R. (2015). Polycentricity and adaptive governance. Working Paper presented at the 15th Biannual International Conference of the International Association for the Study of the Commons, Edmonton, Canada.

Narver, J. C. and Slater, S. F. (1990). The effect of a market orientation on business profitability. Journal of Marketing, 54, 20-35.

Ndubueze, O.J. (2009). Urban housing affordability and housing policy dilemmas in Nigeria. University of Birmingham. Ph.D.

Okafor, B.N. (2016). The residential housing problem in Anambra state (A case study of Onitsha Metropolis). International Journal of Civil Engineering, Construction and Estate Management, 4(2), 22-39.

Olanrewaju, A., Anavhe, P. and Hai, T. (2016). A framework for affordable housing governance for the Nigerian property market. Delivered at the Creative Construction Conference 2016, 25-28 June 2016. Procedia Engineering 164, $307-314$

Pahl-Wostl, C. and Knieper, C. (2014). The capacity of water governance to deal with the climate change adaptation challenge: Using fuzzy set qualitative comparative analysis to distinguish between polycentric, fragmented and centralized regimes. Global Environmental Change, 29, 139-54

Pison Housing Company (2010). Overview of the Housing Finance Sector in Nigeria. In EFInA and FinMark Trust, 2010. Retrieved from https://www.efina.org.ng/wpcontent/uploads/2018/12/EFInAOverview-of-theHousing-Finance-Sector-in-NigeriaAug-2010.pdf in May, 2019.

Rosner, B., Glynn, R.J. and Lee, M. (2006). The Wilcoxon Signed Rank Test for paired comparisons of clustered data. Journal of Biometrics, 62(1), 185-192

Singh, R. (2005). Market orientation and service performance in libraries: An unexplored relationship. Department of Information Studies, Åbo Akademi University, Tavastgatan, Finland

Sitzia, J. and Wood, N. (1998). Response rate in patient satisfaction research: An analysis of 210 published studies. International Journal of Quality Health Care, 10, 311-317

Spearman, C. (1904). The proof and measurement of association between two things. American Journal of Psychology, 15, 72-101

Táborecká-Petrovičová, J., Nedelová, G., Ďad’o, J. and Šályováa, S. (2015). Effect of marketing orientation on business performance: A study from Slovak Foodstuff Industry. Presented at the Business Economics and Management 2015 Conference, Procedia Economics and Finance, 34, 622-629.

Tomášková, I. (2009). The current methods of measurement of market orientation. European Research Studies, 12(3).

Willis, B. and Hyde, C.J. (2014). Estimating a test's accuracy using tailored meta-analysis-How setting-specific data may aid study selection. Journal of Clinical Epidemiology, 67(5), 538-546.

Woolson, R. F. (2008). Wilcoxon Signed-Rank Test. Wiley Encyclopedia of Clinical Trials. Wiley Online Library World Bank (2016). Developing housing finance. Washington: World Bank Publications. 